\title{
LEARNING TO ACT LIKE A LAWYER: A MODEL CODE OF PROFESSIONAL RESPONSIBILITY FOR LAW STUDENTS
}

\section{David M. Tanovich*}

Law students are the future of the legal profession. How well prepared are they when they leave law school to assume the professional and ethical obligations that they owe themselves, the profession and the public? This question has led to a growing interest in Canada in the teaching of legal ethics. It is also led to a greater emphasis on the development of clinical and experiential learning as exemplified in the scholarship and teaching of Professor Rose Voyvodic. Less attention, however, has been placed on identifying the general ethical responsibilities of law students when not working in a clinic or other legal context. This can be seen in the presence of very few Canadian articles exploring the issue, and more significantly, in the paucity of law school discipline policies or codes of conduct that set out the professional obligations owed by law students. This article develops an idea that Professor Voyvodic and I talked about on a number of occasions. It argues that all law schools should have a code of conduct which is separate and distinct from their general University code and which resembles, with appropriate modifications, the relevant set of rules of professional responsibility law students will be bound by when called to the Bar. A student code of conduct which educates law students about their professional obligations is an important step in deterring such conduct while in law school and preparing students for ethical practice. The idea of a law school code of professional responsibility raises a number of questions. Why is it necessary for law schools to have their own student code of conduct? The article provides a threefold response. First, law students are members of the legal profession and a code of conduct should reflect this. Second, it must be relevant and comprehensive in order to ensure that it can inspire students to be ethical lawyers. And, third, as a practical matter, the last few years have witnessed a number of incidents at law schools that raise serious issues about the professionalism of law students. They include, for example, the UofT marks scandal, the Windsor first year blog and the proliferation of blogs like www.lawstudents.ca and www.lawbuzz.ca with gratuitous, defamatory and offensive entries. It is not clear that all of this conduct would be caught by

\footnotetext{
Faculty of Law, University of Windsor. This article is dedicated to my late friend and mentor Rose Voyvodic. It was made possible by a Law Foundation of Ontario research grant. I wish to thank Kevin Wong (09) for his outstanding research assistance. I also wish to thank those that took the time to read this piece and offer their very constructive comments. Earlier versions of this article were presented at "Re-Imagining Access to Justice: A Symposium in Honour of Professor Rose Voyvodic" (19 September 2008); "Professionalism and Serving Communities" ( $11^{\text {th }}$ Colloquium on the Legal Profession) (24 October 2008); and, at a Faculty Seminar, Robson Hall, University of Manitoba (1 November 2008).
} 
University codes of conduct which often limit their reach to on campus behaviour or University sanctioned events. What should a law school code of professional responsibility look like and what ethical responsibilities should it identify? For example, should there be a mandatory pro bono obligation on students or a duty to report misconduct. The last part of the article addresses this question by setting out a model code of professional responsibility for law students.

Les étudiants et étudiantes en droit constituent l'avenir de la profession juridique. Comment bien préparés sont-ils lorsquils quittent la faculté de droit pour assumer leurs obligations professionnelles et éthiques envers eux-mêmes, envers la profession et envers le public? Cette question a mené à un intérêt grandissant au Canada à l'enseignement de l'éthique juridique. Elle a aussi mené à plus d'emphase sur le développement de formation clinique et expérientielle tel que l'exemplifie le savoir et l'enseignement de la professeure Rose Voyvodic. Toutefois, moins d'attention a été consacrée à identifier les responsabilités éthiques générales d'étudiants et étudiantes en droit lorsqu'ils n'oeuvrent pas dans une clinique ou dans un autre contexte légal. Cela se voit dans les faits qu'ily a très peu d'articles canadiens qui portent sur la question, et, de plus grande importance, qu'il y a pénurie, au sein de facultés de droit, de politiques disciplinaires ou de codes déontologiques qui présentent les obligations professionnelles d'étudiants et étudiantes en droit. Cet article développe une idée que jai discuté avec la professeure Voyvodic à un nombre d'occasions. Il soutient que toutes les facultés de droit devraient avoir un code déontologique séparé et distinct du code général de leur université et qui ressemble, avec les modifications appropriées, à l'ensemble pertinent de règlements de responsabilité professionnelle que devront respecter les étudiants et étudiantes en droit lorsquils seront reçus au barreau. Un code déontologique étudiant qui renseigne les étudiants et étudiantes au sujet de leurs obligations professionnelles est une étape importante pour dissuader une telle conduite pendant quills sont à la faculté et pour les préparer en vue d'une pratique fondée sur l'éthique. Le concept d'un code de responsabilité professionnelle pour une faculté de droit soulève un nombre de questions. Pourquoi est-ce nécessaire que les facultés de droit aient leur propre code déontologique? L'article répond en trois temps. D'abord, les étudiants et étudiantes en droit font partie de la profession juridique et un code déontologique devrait refléter cela. Deuxièmement, il doit être pertinent et compréhensif afin d'assurer qu'il puisse inspirer les étudiants et étudiantes à être des avocats qui suivent les normes d'éthique. Et troisièmement, d'ordre pratique, au cours des quelques dernières années, on a été témoins d'un nombre d'incidents à des facul- 
tés de droit qui soulèvent des questions importantes en rapport avec le professionnalisme d'étudiants et d'étudiantes en droit. Ils incluent, par exemple, le scandale au sujet de notes à l'université de Toronto, les blogues de la première année à Windsor et la prolifération de blogues tels que www.lawstudents.ca et www. lawbuzz.ca contenant des commentaires injustifiés, diffamatoires et offensifs. Il n'est pas clair si tous ces comportements seraient captés par des codes déontologiques universitaires dont la portée se limite souvent au comportement sur campus ou aux événements sanctionnés par l'université. Quel aspect devrait présenter un code de responsabilité professionnelle pour une faculté de droit et quelles responsabilités éthiques devrait-il identifier? Par exemple, devrait-il y avoir une obligation pro bono impérative pour les étudiants et étudiantes ou le devoir de rapporter une mauvaise conduite. La dernière partie de l'article porte sur cette question en présentant un modèle de code de responsabilité professionnelle pour les étudiants et étudiantes en droit.

"[Law] [s]tudents need to be treated as professionals so that they will learn to behave as professionals."

\section{INTRODUCTION}

Law students are the future of the legal profession. How well prepared are they when they leave law school to assume the professional and ethical obligations that they owe themselves, the profession, and the public? This question has led to a growing interest in Canada in the teaching of legal ethics. ${ }^{2}$ It has also led to a greater emphasis on the development of clinical and experiential learning as exemplified in the scholarship and teaching of Professor Rose Voyvodic. ${ }^{3}$ Less

1 Leonard Biernat, "Why Not Model Rules of Conduct for Law Students?" (1985) 12 Fla. St. U.L. Rev. 781 at 802 .

2 See Alice Woolley \& Sara Bagg, "Ethics Teaching in Law School" (2007) Canadian Legal Education Annual Review 85; Lorne Sossin, "Can Ethics be Taught” The Lawyers Weekly 26 (6 April 2007) 5; Richard Devlin, Jocelyn Downie \& Stephanie Lane, “Taking Responsibility: Mandatory Legal Ethics in Canadian Law Schools” (2007) 65 Advocate 671; Stephen G. A. Pitel, "The Teaching of Legal Ethics: Recent Developments in Ontario" (2005) 55 J. Legal Educ. 592; and, Jocelyn Downie, "A Case for Compulsory Legal Ethics Education” (1997) 20 Dal. L.J. 224. See further, the general discussion in "Reinvigorating Legal Education" in Adam M. Dodek, "Canadian Legal Ethics: Ready for the Twenty-First Century at Last" (2008) 46 Osgoode Hall L.J. 1 at 32-36. The Law Society of Upper Canada has also begun to take a more active look at the teaching of professional responsibility in law school. See Law Society of Upper Canada, Licensing and Accreditation Task Force, Report to Convocation (20 September 2007) at paras. 8-9, online: The Law Society of Upper Canada <http://www.lsuc.on.ca/news/b/conv/?i=12590>.

3 At the time of her death in April 2007, Professor Voyvodic was Academic Director of Windsor's two student clinics: Legal Assistance of Windsor and Community Legal Aid. As for her scholarship, see Rose Voyvodic, "Lawyers Meet the Social Context: Understanding Cultural Competence” (2006) 84 Can. Bar Rev. 563; Rose Voyvodic, “'Change is Pain:' Ethical Legal Discourse and Cultural Competence” (2005) 8 Legal Ethics 55; Rose Voyvodic \& Mary Medcalf, "Advancing Social Justice Through an Interdisciplinary Approach to Clinical Legal 
attention, however, has been placed on identifying the general ethical responsibilities of law students. This can be seen in the presence of very few Canadian articles exploring the issue; ${ }^{4}$ and more significantly, in the paucity of law school discipline policies or codes of conduct that set out the professional obligations owed by law students. ${ }^{5}$ Part II of the article provides a scan of the codes of conduct or discipline policies of fifteen common law schools in Canada. It also examines the extent to which these law schools have publicly declared professionalism and ethics as a core mission of the school.

This article develops an idea that Professor Voyvodic and I talked about on a number of occasions. It argues that all law schools should have a code of conduct separate and distinct from their general university code and which resembles, with appropriate modifications, the relevant set of rules of professional responsibility law students will be bound by when called to the legal bar. A student code of conduct which educates law students about their professional obligations is an important step in deterring unprofessional conduct while in law school and preparing students for ethical practice. In 1986, the American Bar Association issued a similar recommendation:

Law schools should have - as many do - a code of ethics, including procedures for dealing with disciplinary infractions. Ideally, we believe honor codes should be adapted, insofar as practical, from the Model Rules of Professional Conduct and the ABA Standards for Lawyer Discipline and Disability Proceedings... Law schools should thereby introduce students from the outset of their careers to what it means to be subject to professional standards and processes. ${ }^{6}$

Education: The Case of Legal Assistance of Windsor" (2004) 14 Wash U.J.L. \& Pol'y 101; and, Rose Voyvodic, “'Considerable Promise and Troublesome Aspect:' Theory and Methodology of Clinical Legal Education” (2001) 20 Windsor Y.B. Access Just. 111 at 119-121.

4 My research only revealed one Canadian article on point. See Bruce P. Elman, "Creating a Culture of Professional Responsibility and Ethics: A Leadership Role for Law Schools” (Paper presented to the Eighth Colloquium on the Legal Profession: The Challenges of Leadership, University of Western Ontario, 25 May 2007) online: The Law Society of Upper Canada <http://www.lsuc.on.ca/media/eighth_colloquium_professional_responsibility_ethics.pdf >. In the United States, the issue has generated more academic attention. The seminal article in this area is Leonard Biernat, supra note 1. See also, Steve K. Berenson, "Education Law: What Should Law School Codes Do?” (2005) 38 Akron L. Rev. 803; Brigette L. Willauer, "The Law School Honor Code and Collaborative Learning: Can They Coexist?" (2004) 73 University of Missouri-Kansas City Law Review 514; Elizabeth G. McCulley, "School of Sharks? Bar Fitness Requirements of Good Moral Character and the Role of Law Schools" (2001) 14 Geo. J. Legal Ethics 839; Sarah Ann Bassler, "Public Access to Law School Honor Code Proceedings" (2001) 15 Notre Dame J.L. Ethics \& Pub. Pol'y 207; and, Kimberly C. Carlos, “The Future of Law School Honor Codes: Guidelines for Creating and Implementing Effective Honor Codes" (1997) 65 University of Missouri-Kansas City Law Review 937.

5 For examples of such codes in the United States, see "Professional Conduct Code," Emory Law, online: Emory Law <http://www.law.emory.edu/current-students/registrar/professionalconduct-code.html>; "Law School Code of Conduct" online: The John Marshall Law School $<$ www.jmls.edu/students/pdf/CodeofConduct.pdf $>$.

6 ABA Commission on Professionalism, "In the Spirit of Public Service: A Blueprint for the Rekindling Of Lawyer Professionalism," reprinted in 112 F.R.D. 243 (1986) at 269 [ABA]. 
The idea of a law school code of professional responsibility raises a number of questions. Why is it necessary to have a separate and distinct code of conduct? Part III of the article provides a threefold response. First, law students are an integral part of the legal profession and a code governing their conduct should reflect this. Second, a code of conduct must be relevant to law students in order to ensure that it can inspire them to be ethical members of the profession. And third, as a practical matter, the last few years have witnessed a number of incidents at law schools that raise serious issues about the professionalism of law students. They include, for example, the University of Toronto marks scandal, the University of Windsor first year blog and the proliferation of blogs such as www.lawstudents. ca and www.lawbuzz.ca with gratuitous, defamatory and offensive entries. These and other similar incidents are chronicled in Part III. It is not clear that all of this conduct would be caught by university codes of conduct which often limit their reach to on campus behaviour or university sanctioned events. What should a law school code of professional responsibility look like and what ethical responsibilities should it identify? For example, should there be a pro bono obligation on students or a duty to report misconduct? These questions are addressed at the end of the article where a model code of professional responsibility for law schools is provided.

\section{THE LAY OF THE LAND}

Over the summer of 2008, a scan of fifteen common law schools in Canada was conducted. ${ }^{7}$ The information was obtained from the law school website and from e-mail correspondence with law school officials. ${ }^{8}$ The purpose of the scan was twofold. First, to get a sense of how law schools convey their commitment to ethics and professionalism in their official documents. Second, to determine whether any Canadian law school employs a code of conduct incorporating or modelled after the 'professional rules' that govern lawyers in that jurisdiction.

\section{A. Official Document(s) Identifying Commitment to Professionalism and Ethical Development}

As Bruce Elman, Dean of Windsor Law, has observed "[a] mission statement which states clearly the commitment to ethical lawyering would, I believe, have an impact on prospective students." The same holds true for current students. Since many law schools do not have an explicit mission statement, other documents were examined such as a school's five year strategic plan, student hand-

7 These schools included: University of Victoria ("Victoria"), University of British Columbia (“UBC”), University of Calgary ("Calgary"), University of Alberta ("Alberta”), University of Saskatchewan (“Saskatchewan”), University of Manitoba (“Manitoba”), University of Windsor ("Windsor"), University of Western Ontario ("Western”), Osgoode Hall Law School of York University ("Osgoode”), University of Toronto ("UofT"), Queen's University ("Queens"), University of Ottawa (“Ottawa”), McGill University (“McGill”), University of New Brunswick ("UNB"), and Dalhousie University ("Dalhousie").

8 A copy of the completed scan was also e-mailed to all Deans and Associate Deans to ensure that all relevant material was examined.

9 Elman, supra note 4 at 2. 
book or statement of objectives or values. Many of the law schools scanned (e.g. Victoria, ${ }^{10}$ UBC, ${ }^{11}$ Alberta, ${ }^{12}$ Calgary, ${ }^{13}$ Saskatchewan, ${ }^{14}$ Manitoba,,${ }^{15}$ Windsor, ${ }^{16}$ Western, ${ }^{17}$ Osgoode, ${ }^{18}$ Uof $T,{ }^{19}$ Queens,${ }^{20}$ and Ottawa ${ }^{21}$ ) have a document that

10 The UVic Faculty of Law Policy on Academic Integrity begins with, "Students at the Faculty of Law are expected to observe high ethical standards not only as students but also as potential members of the legal profession. The Faculty trusts its students to act with propriety and integrity in their relationships with each other and with the Faculty, in both academic and non-academic endeavours," online: University of Victoria Law <http://www.law.uvic.ca/Current_Students/ Academic_Regs/Academic-Regs.php\#academic>.

11 See infra at note 23.

12 The Law Faculty Council Mission Statement states that "[t]he mission of the Faculty of Law is to provide service to the community, to educate prospective lawyers and others seeking a thorough understanding of the law and the legal system, and to promote the acquisition of legal knowledge and the advancement of legal scholarship, in an environment based on equality, support, respect and recognition for the unique and diverse contributions of all its members." See Law Faculty Council Policy Manual (2007) at 1, online: University of Alberta Law <http:// www.law.ualberta.ca/Faculty--Research/Administration/Law-Faculty-Policy-Manual.php>.

13 Two of the Calgary objectives are " $[\mathrm{t}]_{\mathrm{o}}$ familiarize the students with the ethical and professional responsibility dimensions of law and its practice;" and, "[t]o instil in students a sense of obligation to be full contributing members of their communities." See Program Objectives, online: University of Calgary Faculty of Law <http:/www.law.ucalgary.ca/programs/llb/ objectives $>$. In addition, in discussing academic misconduct, Calgary observes that "[e]ntry into the legal profession requires the highest ethical conduct possible...." See Faculty Regulations, online: University of Calgary Faculty of Law <http://www.law.ucalgary.ca/current/regulation>.

14 The Mission Statement states that "The College of Law at the University of Saskatchewan is committed to providing critical and reflective education so students have the best academic preparation for assuming professional responsibilities in the humane operation of the legal system and for all vocations in which an understanding of law is necessary or helpful," online: University of Saskatchewan College of Law <http://www.usask.ca/law/about_us/index.php>.

15 The Manitoba Law School Frequently Asked Questions page states that "As well, the program offers a sense of professionalism and emphasizes the professional responsibilities of lawyers in terms of ethics and service to clients and the public." online: University of Manitoba Faculty of Law <http://www.umanitoba.ca/law/newsite/faq.php>.

16 See the discussion below.

17 The Western Law: A Strategic Plan (2006), online: Western Law <http://www.law.uwo.ca/infogeneral/StrategicPlan06.pdf > identifies the Western Law School Values as:

- Leadership - in teaching, in research and law reform

- Diversity - in our curriculum, in our scholarly interests and in our student community

- Collegiality and Partnership - in our mission

- Responsibility - to one another, and to our law school, for the accomplishment of our goals

- Integrity - in our dealings with students, with one another, and with the community.

18 Discussed infra at note 27.

19 Discussed infra at note 24.

20 Discussed infra at note 22.

21 The LLB Objectives, online: University of Ottawa Faculty of Law <http://www.commonlaw. uottawa.ca/index.php?option=com_content $\&$ task=blogcategory \&id=141\&Itemid=136 \&pid=136\&lang=en $>$ page states:

... As a professional program, the [Common Law] Section prepares students for entrance to the practice of law .... These professional and intellectual objectives are achieved in a manner which is mindful of the privilege and power often accorded to lawyers in our society. Our students are future leaders. Our programs concentrate on more than just the letter of the law. We address the spirit of the law and the ideal of justice. In our view, it is the duty of the program to respect and promote the full range of diversity reflecting the multi-lingual, multi-cultural and multi-racial characteristics of the women and men in our programs and in Canadian society. 
identifies the importance of ethics and professionalism or, at a minimum, placing it, or some aspect of professionalism, as an integral learning outcome or law school value.

However, there is a significant degree of variance in the details contained in these statements. Queens, for example, simply places "Professionalism" as a value in their Law Strategic Framework (2005-2010) without any definition or discussion. ${ }^{22}$ Similarly, UBC's Dean's Message states that "UBC has become one of the best law schools in the world by ... providing practical skills training in advocacy, alternative dispute resolution, legal research and writing, problem solving and ethics ..."23, while UofT refers to its "dedication to the public good" and to exposing its students "to the inherent value of public service" in its Degree Level Expectations. ${ }^{24}$ Slightly more detail is provided by Western's Strategic Plan (2006) that identifies some of the elements of professionalism including "collegiality," "responsibility," and "integrity" as core values of the law school..$^{25} \mathrm{~A}$ strong statement of commitment to ethics is provided by Victoria ${ }^{26}$ and Osgoode. For example, in its Plan for the Law School 2006-2010, Osgoode states that:

It is critical that our student body learn about and appreciate the role of law and lawyers in society, the role of our legal institutions, and how lawyers can assist their clients with an extremely high degree of ethics....

At the heart of Osgoode's values is the concept of a profound ethical concern, one that seeks to increase students' awareness of the relationship between law and society and their professional and scholarly responsibility not only to individual clients but also to the community at large ...."

... Legal ethics is a critically important aspect of a legal education. It is a fundamental tenet of a professional legal education. $^{27}$

Windsor provides the most comprehensive approach with a number of official

22 Queen's Law Strategic Framework 2005-2010 at 3, online: Queens University <http://law. queensu.ca/strategicPlanning.html>.

23 Online: UBC Faculty of Law <http://www.law.ubc.ca/welcome/index.html $>$.

24 On file with the author. In its prospectus for future students, Uof T notes that " $[\mathrm{a}] \mathrm{t}$ Uof T ... public service is a critical component of the faculty's mission and of every law school student's legal education. From the first day of law school, students are expected and encouraged to demonstrate social responsibility through their involvement in the many public interest opportunities ...” See J.D. Program (2008-2009) at 17, online: University of Toronto Faculty of Law <http://www.law.utoronto.ca/prosp_stdn_content.asp?itemPath=3/6/0/0/ $0 \&$ contentId=1036\&cType=webpages $>$

25 Supra note 17.

26 Supra note 10.

27 Plan for the Law School 2006-2010 at 6, 11, 13. On file with the author. See also, "Raising Ethical Lawyers" (2008) Continuum (Osgoode Alumni Magazine) at 8, online: Osgoode Alumni <www.osgoodealumni.ca/documents/Continuum2008.pdf>. 
documents committing the school and its students to professionalism and ethical development. The Statement of Objectives states that the central goals of the school include:

5. To create a sensitive, caring and supportive environment for the study of law, enhancement of professionalism...

6. To create an academic and social environment conducive to learning and to the personal development of students, particularly women and those who are socially and economically disadvantaged, differently abled, late vocational, and from Aboriginal and various ethnic backgrounds, and in particular:

a. To provide opportunities for the development of social consciousness and self-awareness by students, and to examine and develop ethical and social values in relation to personal and professional responsibility, and in particular, to instil in the students a sense of social responsibility in the practice of law and the need for the examination of social structures with a view to contributing to such changes as may ensure social justice ...

e. To foster in students an attitude of fairness and openness in dealing with others, free of bias. ${ }^{28}$

In 2006, Windsor created LEXpectations based on Duke University Law School's Blue Notes. ${ }^{29}$ The document is given to every student and is posted outside the General Office:

\section{Engage Intellectually}

[Text omitted]

\section{Embody Integrity}

- Be truthful, candid, fair, even if your actions go unnoticed; know that acting honourably often requires effort

- Articulate your personal code of ethics in the context of the rules governing the Law School and the legal profession

- Use ambiguous situations as an occasion to cultivate sound judgment, and avoid even the appearance of impropriety

- Transform controversy and conflict at the Law School into opportunities to work constructively with others for the benefit of the community

28 University of Windsor, Faculty of Law, Calender 2006-2008 at 5. Online University of Windsor Law <http://www.uwindsor.ca/units/law/lawTop.nsf/831fc2c71873e46285256d 6e006c367a/ 27536300d0e48b4185256dca005a6f1b/\$FILE/LawCalendarWEB.pdf >. The statement should be read to include racialized students and students from sexual minorities.

29 Elman, supra note 4 at 6 . 


\section{Lead Effectively}

[Text omitted]

\section{Build Relationships}

[Text omitted]

\section{Serve The Community}

- Volunteer for a service activity designed to benefit the community

- Engage in pro bono activities before you graduate

- Identify public issues that are important for you, form connections with others involved in these issues, and work to make a difference

\section{Practice Professionalism}

- Treat everyone with respect, even in the midst of disagreement

- Collaborate with others to achieve common goals; be mindful of the appropriate time and place for competition

- Take pride in your work and responsibility for your actions

\section{Live With Purpose P $^{30}$}

[Text omitted]

Finally, Windsor has identified the following learning outcome:

\section{Responsible behaviour to self, others and society}

The responsible behaviour of a law student/lawyer requires a familiarity with the rules of professional conduct and the principle of civility as well as an understanding of the ethical obligations owed to clients, the legal system, the profession and the general public. Law students must be able to articulate these ethical obligations and be able to relate them to the behaviour expected of them throughout law school. ${ }^{31}$

\section{B. The Current Content of Law School Discipline Policies}

In addition to mission/objective statements, there are other ways in which a law school can demonstrate and inculcate a commitment to the ethical development of its law students. These include the creation of a professionalism centre; $^{32}$ a mandatory ethics/professional responsibility course; ${ }^{33}$ pervasive eth-

30 LEXpectations - Lawyer Education and Development, online: University of Windsor Law online: University of Windsor Law <http://www.uwindsor.ca/units/law/lawTop.nsf/ SubCategoryFlyOut/C2C5531E08D8024E852572A400483B95>.

31 Faculty of Law Learning Outcomes. On file with the author. See also, Raising the Bar: A Plan of Action for Windsor Law School 2006-2012 at 7, online: University of Windsor Law <http:// www.uwindsor.ca/units/law/LawTop.nsf/inToc/B4AF84C655BCE4E38525714B004D6A75? OpenDocument>.

32 The UofT Faculty of Law has recently established the "Centre for Legal Professionalism" whose goal is "to broaden and deepen our understanding of professionalism, ethics and public service, and the relationship between them." Online: University of Toronto Faculty of Law <http:// www.law.utoronto.ca/visitors_content.asp?itemPath=5/12/0/0/0\&contentId=1602>.

33 Currently, eleven (11) law schools in Canada have either a mandatory ethics/professional responsibility course or a significant part of their first year curriculum devoted to legal ethics. These schools include UBC, Alberta, Calgary, Manitoba, Windsor, Western, Osgoode, Toronto, 
ics teaching; a focus on clinical and experiential learning; internships; and, a code of professional responsibility for law students. The focus of this article is on the latter. Codes of conduct are an important part of the professionalization process in law school because their purposes include: to educate, to exhort and reinforce the values and goals of the profession, to inspire, and to regulate and deter misconduct. ${ }^{34}$ In the context of a law school code, one commentator has noted that the purposes include "(1) to educate the students about appropriate ethical conduct; (2) to reinforce ethical principles already considered important; and (3) to serve as an incentive for students to act in ethical ways." 35

A scan of the common law schools reveals that the norm is for law schools in Canada to have a policy setting out only academic misconduct offences (e.g. Victoria, ${ }^{36}$ Alberta, ${ }^{37}$ Calgary, ${ }^{38}$ Western, ${ }^{39}$ Queens, ${ }^{40}$ Ottawa, ${ }^{41}$ and Dalhousie ${ }^{42}$ ) and then to rely on the general university policy or code of conduct and nondiscrimination/harassment policy to govern non-academic misconduct. ${ }^{43}$ With the exception of Victoria, ${ }^{44}$ none of these policies begin with a discussion of the special obligations owed by law students. ${ }^{45}$ Other law schools rely on their general University code for both academic and non-academic misconduct (e.g.

Ottawa, UNB and Dalhousie. See Dodek, supra note 2 at 34; and Devlin Downie and Lane, supra note 2 at note 3 . The importance of mandatory courses to ethical development has now been made in a number of Canadian articles and will not be addressed here. This academic literature is cited at supra, note 2 .

34 See Berenson, supra note 4 at 810-811, 825-831; and, Bassler, supra note 2, 207 at 209-213.

35 Bassler, supra note 2 at 210.

36 Policy on Academic Integrity, online: University of Victoria Law <http://www.law.uvic.ca/ Current_Students/Academic_Regs/Academic-Regs.php\#academic >.

37 Alberta only has an exam cheating provision as part of their Law Faculty Council Policy Manual at 64 (section 30.18), online: University of Alberta Law <http:/www.law.ualberta.ca/FacultyResearch/Administration/Law-Faculty-Policy-Manual.php $>$. Reliance is placed on its University Code for other academic offences.

38 Calgary only has exam cheating provision as part of their Law Faculty Council Policy Manual at 11, online: University of Calgary Faculty of Law <http://wcm2.ucalgary.ca/law/files/law/ regulations.pdf $>$. Reliance is placed on its University Code for other academic offences.

39 Professional Responsibility Policy, online: Western Law <http://www.law.uwo.ca/Current/ ProfessionalResponsibility.html>.

40 Faculty of Law Plagiarism and Academic Dishonesty Regulations, online: Queens University $<$ http://www.queensu.ca/calendars/law/pg77.html>.

41 Faculty of Law Academic Fraud Policy, online: University of Ottawa Faculty of Law $<$ http://www.commonlaw.uottawa.ca/index.php?option=com_content\&task=blogcategory\&id $=35 \&$ Itemid $=468$ pid $=46 \&$ lang $=$ en $>$.

42 Faculty Policy on Avoiding Plagiarism in Legal Writing, online: Dalhousie Law School <http:// law.dal.ca/Current_Students/Course_Selection_Materials/Regulations_Handbook/Plagiarism_ Policy/index.php >. See also, "H. Examination Regulations" Faculty of Law Calendar 20082009, online: Dalhousie University <http://dlm.cal.dal.ca/_LAWS.htm\#1>.

43 The University of Ottawa is in the process of approving a Student Code of Non-Academic Conduct. It is one of the only universities in the country without such a code. See "The University of Ottawa consults its community on the student code of conduct," online: University of Ottawa <http://www.media.uottawa.ca/mediaroom/news-details_1458.html>.

44 Supra note 10

45 Victoria also has policy governing clinic students. See Student Conduct and Competence in Clinical Programs, online: University of Victoria Law <http://www.law.uvic.ca/Current_ Students/Academic_Regs/Academic-Regs.php\#student>. 


\section{UBC, Saskatchewan, Manitoba, Osgoode, ${ }^{46} \mathrm{UofT}^{47}{ }^{4} \mathrm{McGill},{ }^{48}$ and, $\left.\mathrm{UNB}^{49}\right)$.}

Alberta is interesting because it has incorporated the Alberta Code of Professional Responsibility into its university code of conduct. Section 30.3.3(2) places an obligation on all law students to obtain and be familiar with the Alberta Code, while section 30.3.3(1) states that "[a] Student enrolled in a Professional

46 Osgoode Student Handbook (2007) at I.4-I.7 (non-academic misconduct); II.30-II.37 (academic misconduct) (on file with the author). Osgoode does, however, have an anti-discrimination standard of conduct in its Student Handbook at I.2-I.4. It includes the following:

A. Osgoode Hall Law School Equality Resolution

\section{...2. Affirmation}

Osgoode Hall Law School, its staff, students and faculty, subscribe to the public policy enunciated in the preamble to the Ontario Human Rights Code, and state expressly that they seek to do everything possible to enhance that policy within the Law School community. To this end the Law School affirms that every member of the community has a right to equal treatment without discrimination, and in particular, without regard to race, ancestry, place of origin, colour, ethnic origin, citizenship, creed, political orientation, sex, age, marital status, sexual orientation, family status, or handicap.

...3. Teaching and Learning

The faculty and students, in order to continue and expand efforts to promote freedom from discrimination both within the Law School and in society at large, undertake to consider the following measures in relation to teaching and learning:

...b. use of language in the classroom...that is free from discriminatory stereotypes and references...

...d. a heightening awareness of the existence of systemic discrimination.

B. Osgoode Hall Law School Equality Procedures

1.1 Standards of Conduct - General Principles

b. Members of the Osgoode Community have a right to be free from discrimination or harassment directed at their race, ancestry, place of origin, colour, ethnic origin, citizenship, creed, political orientation, sex, age, marital status, sexual orientation, family status or handicap.

c. Any intellectual community thrives on the free and full expression of opposing ideas and values. However, only in an environment free of discrimination or harassment can the Law School fulfil its commitment to fostering an environment that promotes free and open inquiry by all members of the community. Students, staff and faculty have a responsibility to exercise their freedom of expression in a manner that promotes equality and justice.

47 Faculty of Law Syllabus and Academic Handbook 2008-2009 at 6, online: University of Toronto Faculty of Law <http://www.law.utoronto.ca/students_content.asp?itemPath=2/2/12/0/ 0\&contentId $=442>$.

48 Faculty of Law Calendar 2007-2008 at 9.2 Student Rights and Responsibilities and 9.5 Academic Integrity, online: McGill University <http://coursecalendar.mcgill.ca/law200708/wwhelp/ wwhimpl/js/html/wwhelp.htm>.

49 Online: University of New Brunswick <http://law.unb.ca/unbpolicies.html>. UNB does have its own language policy which states:

a. Language Policy

It is the policy of the Law Faculty Council that:

1. In all professional and law school related communication, members of the Faculty of Law community avoid language and conduct that can be understood reasonably to be sexist, racist, homophobic or for similar reason objectionable; and

2. Members of the Faculty of Law community use, as far as possible, gender neutral or gender inclusive language, except where gender exclusive language might usefully sensitize the listener or reader to stereotypical thinking.

Faculty of Law Regulations at C.18, online: University of New Brunswick Law School <http:// law.unb.ca/pdf/regulations.pdf>. 
Program is bound by and shall comply with the Professional Code of Ethics governing that profession and the practice of its discipline." The problem is that violation of the Law Society of Alberta Code only becomes a disciplinary offence where the student is involved in a Practicum Placement. ${ }^{50}$ Moreover, incorporation is not sufficient. If a law school code is to achieve its purpose of education and aspiration, it must, as discussed later, specifically identify the professional obligations owed by law students. For example, a student's duty of competence and civility will be different from that owed by lawyers.

Windsor is the only law school that has its own autonomous discipline policy. It specifically incorporates some of the professional obligations owed by law students. ${ }^{51}$ The policy begins with a discussion of law as an honourable profession, the duties owed by lawyers to their clients, the courts, the public and their fellow members, and the obligation of law students to act with both educational and professional integrity. With respect to the latter, the policy states:

The term "integrity" and its expression herein is drawn from the Canadian Bar Association Code of Professional Conduct, ch. 1, which has been adopted by the Law Society of Upper Canada. The spirit and intent of the Code which requires civility, candor, honesty, and adherence to sound moral principle shall be observed by all law students in their personal and academic behaviour to the end that credit shall be reflected upon the Law School and the legal profession.

... [I]t is fundamental to the study of law and to the maintenance and betterment of the community of scholarship which is the Law School that the faculty and students adhere to and foster the highest standards of integrity including trustworthiness, truthfulness, fair dealing, uprightness, honesty and sincerity.

Any student at the Faculty of Law whose conduct is improper in that it exhibits a lack of integrity touching the educational and professional objectives of the University, the Law School, or the profession must be appropriately disciplined in the interests of safeguarding and upholding these standards. ${ }^{52}$

50 Section 30.3.3(3) states:

A Student enrolled in a Professional Program who contravenes the Professional Code of Ethics governing the profession and the practice of its discipline commits an offence under this Code when, at the time of the alleged offence, the Student is involved in a Practicum Placement related to a course of study in a Professional Program.

Section 30.3.3(4) identifies specific conduct that constitutes unprofessional conduct when working in a Practicum Placement. See Code of Student Behaviour, online: University of Alberta <http://www.uofaweb.ualberta.ca/gfcpolicymanual/content.cfm?ID_page=37633\#38365>.

51 Enacted as University of Windsor, Faculty of Law, Policy Statement on Student Discipline, online: University of Windsor Faculty of Law <http:/www.uwindsor.ca/units/law/lawTop.nsf/inToc/ 3DCC59996A526AD585256D87005686A5> [Windsor Discipline Policy].

52 Ibid (emphasis added). 
The Windsor policy also extends the Law Society of Upper Canada's Rules of Professional Responsibility to clinic students and, as well, to "law students engaged in activities analogous to the practice of law such as mock trials and mooting." Perhaps, even more significant, is that "this provision has been interpreted very broadly over time to include almost any student activity to which the Code of Professional Conduct could be applied." 53

While a good start, the Windsor policy has a number of shortcomings. With the exception of malicious harassment and improper conduct in the provision of legal services, all of the specific instances of misconduct relate to academic misconduct or misuse of campus facilities. More significantly though, with the exception of integrity, honesty and civility, the policy does not identify or discuss the other professional values that law students should aspire to. For example, there is no discussion of service, competence, confidentiality (with the exception of disciplinary proceedings) or the duty to not discriminate. It also does not address whether or not there is a duty on students to report misconduct. Of course, as Dean Elman has observed, these obligations may nevertheless exist through incorporation of the Rules of Professional Responsibility.

\section{WHY A LAW SCHOOL CODE OF PROFESSIONAL RESPONSIBIL- ITY IS NECESSARY?}

\section{A. Law Students as an Integral Part of the Legal Profession}

In 1986, the American Bar Association took the view that "law students should be viewed as members of the legal profession from the time they enter law school." ${ }^{4}$ In addition, as noted earlier, they recommended that law students should be subject to a code of conduct that reflected this status. This is a very reasonable position to take. While law school is an academic institution, it is primarily, or at least has evolved in North America, to become a professional school. ${ }^{55}$ Indeed, I suspect that well over ninety-five (95) percent of students come to North American law schools intending to get called to the Bar. ${ }^{56}$ And, even those who decide to teach, enter politics or work for a non-governmental organization, will likely remain members of their relevant professional body and, therefore, subject to its ethical rules.

But perhaps, more significantly, admission to law school is the key to becoming a legal professional because there is no other meaningful vetting process

53 Elman, supra note 4 at 8.

54 ABA, supra note 6 at 266. See also Richard Devlin, "Normative, and Somewhere to Go? Reflections on Professional Responsibility” (1995) 33 Alta. L. Rev. 924 at 929 where he observes that "[s] tudents ... are active members of the legal community and also have much to contribute to the questions of professional responsibility."

55 William M. Sullivan et al., Educating Lawyers: Preparation for the Profession of Law (San Francisco: Wiley \& Sons Inc., 2007) at 91-95. See also, American Bar Association, Legal Education and Professional Development - An Educational Continuum (Report of the Task Force on Law Schools and the Profession: Narrowing the Gap) (the "MacCrate Report") (Chicago: American Bar Association, 1992).

56 The likelihood that students will choose law school as part of a liberal education as opposed to a professional school has and will likely continue to decrease with the rise in tuition. 
besides the articling requirement. This point is made by Adam Dodek in his address to his first-year students:

Your entry into the legal profession begins on Day 1 of law school because (1) few students fail law school; and (2) few - if any - fail bar admission courses. You may "exit" either option by choice, but very few of you will have that choice made for you. ${ }^{57}$

Thus, the privileges of law school extend beyond education, to the right to engage in student lawyering (defined broadly to include clinic work, pro bono work, mooting, internships, and clerking), to be a summer associate and ultimately the right to be a legal practitioner. The number of students involved in student lawyering in law school should not be underestimated. In addition to clinic work, more and more law students are serving our communities through pro bono placements. Indeed, Pro Bono Students Canada reports that it engages approximately 2,000 law students per year. Students working in these positions need to be aware of their professional obligations and ensure that their words and conduct do not further marginalize the very communities they are serving. ${ }^{58}$ Public trust and confidence demands nothing less.

With these privileges come special obligations including the obligation to develop a professional conscience, to learn how to be professionally responsible, ${ }^{59}$ a duty of confidentiality, a duty to be culturally competent and a duty to protect the reputation of the law school and profession. Consequently, a law school's mission must include teaching all students about professionalism and demanding that they act like professionals. ${ }^{60}$ This is recognized, for example, by Osgoode in its Plan for the Law School 2006-2010:

In providing a professional education, we believe it important

57 E-mail from Adam Dodek (21 August 2008) (on file with the author).

58 See Pro Bono Students Canada, online: Pro Bono Students Canada <http://www. probonostudents.ca/en/>.

59 Or how to rely on "WWRVD." At Windsor, students who had the privilege of having Professor Voyvodic as a teacher and mentor coined this expression in her honour. It means "what would Rose Voyvodic do" when confronted with a difficult situation. In an acceptance speech she wrote for the Charles Clark award a few days before her death, Rose provided the following insight into her ethical yardstick:

My own compasses of heart and mind have done me well in prioritizing the need to find social justice where we can, and, perhaps more importantly, in learning how to self-reflect so that I learn from my mistakes .... [T] he best way I have of telling myself I have made a mistake (ethical, legal, moral or just bad behaviour) or am about to make one is still whether or not my head feels right on my pillow at the end of the day, corny as that sounds.

See "Law community celebrates Rose Voyvodic's Life" The Windsor Star (30 September 2007); and, "Rose Voyvodic's Remarks as Recipient of the Charles Clark Award, 2007," (2007) 3 CAVEAT at 2, online: Essex Law Association <www.essexlaw.ca/caveat/Caveat2007-05.pdf>.

60 Downie relies on this argument in support of mandatory legal ethics education in law school. See Downie, supra note 2 at 226-227. 
to provide not just a sound training in legal reasoning and in the technical aspects of law, but also a deeper understanding of the social and ethical roles and responsibilities of members of the legal profession. ${ }^{61}$

In its Consultation Paper on the Canadian common law degree, the Federation of Law Societies' Task Force on the Canadian Common Law Degree similarly observed:

Both the profession and the legal academy have a responsibility to develop and nurture a sense of professionalism in students and lawyers. ${ }^{62}$

The authors of the Carnegie Foundation's Educating Lawyers: Preparation for the Profession of Law note that " $[\mathrm{p}]$ rofessional education aims to initiate novice practitioners to think, to perform, and to conduct themselves (that is, to act morally and ethically) like professionals." 63

General university codes of student conduct are not up to the task. ${ }^{64}$ They are usually more focussed on discipline rather than on creating a culture of professionalism. Nor are they adequate to teach law students about legal professionalism. They do not, generally speaking, address issues of public service, competence, confidentiality, or a duty to report misconduct. In addition, having a separate law school code of conduct focussed on the professional obligations of law students is an important part of experiential learning. Over the last decade, law schools have come to recognize that one of the most effective ways in which to get students to "think like a lawyer" is experiential learning, including clinical work, internships, and mooting. The same is true for the development of professionalism. As has been observed:

This cannot be learned through lecture or by reading - it can only be learned through the experience of knowing and understanding one's professional obligations and faithfully carrying out those duties. At the same time, legal educators cannot teach professional responsibility solely by lecturing and giving reading assignments. Professional responsibility can be inculcated only by giving students responsibilities and by cultivating their professional and ethical growth. The development and use of an ethical code of conduct for law students may be an appropriate vehicle through which law

61 At 3. On file with the author.

62 Online: Federation of Law Societies of Canada <http://www.flsc.ca/en/pdf/2008Consultation_ paper.pdf> (September 2008) at 21. One of the recommendations of the Task Force is a mandatory legal ethics course in law school.

63 Sullivan et al, supra note 55 at 22.

64 Recall here that I am only examining the role of codes of conduct in inculcating professionalism. Earlier, I identified other important steps a law school can take including mission statements, ethics courses, clinical and other experiential learning. 
students may gain additional responsibility. ${ }^{65}$

This learning process could be enhanced by giving law students an opportunity to participate in the structure and content of a code, as well in the disciplinary hearings. A code and any subsequent opinions could also be used in class as a starting point for discussions of ethics and professionalism.

Finally, while one would expect all university students to act responsibly, one of the hallmarks of being a member of a profession is the expectation, as noted above, that its members have "special responsibilities by virtue of the privileges" associated with that profession. ${ }^{66}$ As noted earlier, law school students enjoy privileges their other student counterparts do not. So, for example, general university codes do not usually impose a service obligation on its students or a duty to report misconduct. Nor do they always extend their jurisdiction into the private lives of students as far as may be necessary to ensure that law students do not bring disrepute to the law school and profession.

And so, as Dean Elman has observed, "[t]he purpose of having a separate policy is clear - it is designed to give effect to the professional elements of the law program and emphasize to the student that they are going to be held to standards similar to that of members of the legal profession, even while they are preparing educationally for a career in law." ${ }^{67}$

\section{B. A Professionalism Crisis}

\section{In Practice}

The last decade has witnessed a number of high profile incidents of unprofessional conduct ranging from the suppressing of evidence in a high profile murder case ${ }^{68}$ intemperate and uncivil conduct in the courtroom; ${ }^{69}$ to the Treasurer of the Law Society of Upper Canada being suspended because of a sexual relationship with a client. ${ }^{70}$ With these incidents has come a renewed emphasis on professionalism in the legal profession. We have seen the creation of an Advisory Committee on Professionalism in Ontario headed by the Chief Justice of Ontario (September 2000); ${ }^{71}$ the promulgation of a working definition of professionalism $;^{72}$ the creation of a rotating Colloquium on the Legal Profession

65 Biernat, supra note 1 at 804 .

66 Rule 1.03(1)(a), Rules of Professional Responsibility (Law Society of Upper Canada, 2008), online: The Law Society of Upper Canada <http://www.lsuc.on.ca/regulation/a/ profconduct/>.

67 Elman, supra note 4 at 7.

68 See R. v. Murray (2000), 144 C.C.C. (3d) 289 (Ont. S.C.J.).

69 See R. v. Felderof (2003), 68 O.R. (3d) 481 (C.A.); and Marchand v. Public General Hospital Society of Chatham (2000), 51 O.R. (3d) 97 (C.A.).

70 See Law Society of Upper Canada v. Hunter, [2007] L.S.D.D. No. 8. These incidents and others are chronicled in Dodek, supra note 2 at 9-13.

71 See Law Society of Upper Canada, Chief Justice of Ontario's Advisory Committee on Professionalism, online: <http://www.lsuc.on.ca/latest-news/a/hottopics/committeeonprofessionalism/>.

72 See Chief Justice of Ontario Advisory Committee on Professionalism, Working Group on the Definition of Professionalism, "Elements of Professionalism" (October 2001, rev. December 2001, June 2002), online: The Law Society of Upper Canada <http://www.lsuc.on.ca/latest- 
at Ontario's six law schools; and, a code of civility enacted by the Advocate's Society (Ontario) and adopted by the Canadian Bar Association. ${ }^{73}$ While these initiatives are largely focussed on the practicing bar, a code of conduct for law students would begin the professionalization process much earlier. As Jordan Furlong so aptly puts it in "Professionalism Revived: Diagnosing the Failure of Professionalism among Lawyers and Finding a Cure:”

By the time students finish law school, they will have spent three years learning about the purpose of the law, but not about the purpose of lawyers. It is unacceptable that a lawyer may progress three years into her career without receiving lengthy and illuminating instruction in legal professionalism.... If lawyers do not understand the nature and importance of professionalism from the start, they will not believe it is important, and they will not practise it. ${ }^{74}$

\section{In Law School}

\section{(a) High Profile Incidents at UofT and Osgoode}

Law schools have not been immune to the professionalism crisis. There have been a number of high-profile incidents of unprofessionalism at Canadian law schools. The most notable being three incidents in 2001: the UofT marks scandal involving two dozen students; ${ }^{75}$ overtly racist acts at Osgoode Hall Law School targeting Black students during Black history month; ${ }^{76}$ and, an Islamaphobic article written by an Osgoode student in Obiter Dicta, a student newspaper. ${ }^{77}$

news/a/hottopics/committee-on-professionalism/>. The identified ten "building blocks" of professionalism include: scholarship, integrity, honour, leadership, independence, pride, spirit, collegiality, service and balanced commercialism.

73 Principles of Civility for Advocates, online: The Advocates' Society <http://www.advocates.ca/ pdf/100_Civility.pdf>. See also, the discussion in Alice Woolley, "Does Civility Matter?” (2008) 48 Osgoode Hall L.J. 175 at 177.

74 Paper presented to the Tenth Colloquium on the Legal Profession: Professionalism: Ideals, Challenges, Myths and Realities, University of Ottawa, 8 March 2008, online: Law Society of Upper Canada <http:/www.lsuc.on.ca/latest-news/a/hottopics/committee-on-professionalism/ papers-from-past-colloquia/> at 11 .

75 In 2001, more than two dozen students were alleged to have misrepresented their first year grades to potential summer employers. Twenty-four students received some form of sanction. See James Cowan, “Atonement: When 24 students at UofT's Faculty of Law lied about their grades to land summer jobs, they tarnished the school's reputation and risked their own futures" (June 2001) 36:9 Toronto Life. See also, Shanks v. Daniels (2002), 57 O.R. (3d) 539 (Sup. Ct. J.).

76 The acts included letters sent to two Black female law students. The letters contained newspaper clippings about crimes involving racialized suspects and the words "It disgusts me to see you at Osgoode." In another incident, the eye of a Black woman whose picture was posted on the bulletin board of the Black Law Students Association was poked with a pin. See Nicholas Keung, "Racism Targets York Law School: Black Students Look for Justice After Hate Letters" Toronto Star (22 February 2001). See also, "Notice to the Osgoode Community" (21 February 2001) (on file with the author).

77 For example, the article condemned Islam as "oppressive, backwards and brutal." See, Adrian Humphreys, "Osgoode Hall Apologizes for Anti-Islam Article” National Post (1 May 2001). 
A more recent incident involved a former Osgoode student, who was found to have engaged in conduct unbecoming a student licensee for selling papers he had written, to a student in the MBA program at York University. The agreed statement of facts read in at the Law Society hearing revealed that the student and another Osgoode student wrote papers for the same student while all three were in law school. ${ }^{78}$

\section{(b) Windsor Law Incidents}

It is difficult, however, to get a real sense of how many other incidents there are in law schools since most incidents go unreported or are not publicized outside of the particular law school community. ${ }^{79}$ As I teach at Windsor Law, I have firsthand information about a number of incidents that reveal the scope of unprofessionalism in our midst. Some of these include: ${ }^{80}$

\section{The Blawg for Beginners (The Unofficial Windsor Law Blog) (2006)}

A number of first-year students decided to start a blog to "tell us about anything ... what's goin'on in the city what's goin' on in your life, what your beef is with school, you name it... you write it, we'll post it. That's right. The colour of justice of our blog is not necessarily white." The URL of the blog was http://windsorlawblog. blogspot.com/. The links on the first page included the UWindsor Faculty of Law Page; Turtle Rape and TubGirl. The blog reached well over one hundred and fifty (150) pages of entries before it was eventually removed from the web in early 2007 following my complaint to the Associate Dean. ${ }^{81}$

The blog contained numerous offensive and demeaning entries targeting racialized and female professors as well as female students. The following entry reveals the tone of many of the blog's entries:

78 See Robert Todd, “Toronto Lawyer Fined in Cheating Scandal” Law Times (26 January 2008).

79 For a dated but still very relevant article describing incidents of violence against women at law schools, see Teresa Scassa, "Violence Against Women in Law Schools"(1992) 30 Alta. L. Rev. 809. See also, Sheila McIntyre, “Gender Bias within the Law School: 'The Memo' and Its Impact" (1987) 2 C.J.W.L. 362.

80 The Administration has responded to these and other incidents in a number of ways. First, the Dean issued two stern letters to the student body reminding them of the duty to act like professionals, including the duty not to discriminate, and to respect the dignity of their colleagues. Second, professionalism now features prominently in our first year orientation. Third, two consultants have been retained to provide training to faculty about addressing discriminatory incidents and comments. There are similar plans to provide cultural competence training to the student body. Fourth, there is now a requirement that all professors attach the University's Human Rights Policy to their syllabi. And, finally, there is a commitment to overhaul our discipline policy.

81 A copy of the blog is on file with the author. 
A Manly Man's Guide to “Friends with Benefits (by Harry Ballsonya)

*Disclaimer: before all you feminist lesbians get your boxer-briefs in a bunch, remember that this is JUST A JOKE. I'm not condoning insensitivity, sex with strangers, or sex with any of you. So relax! or better yet, if your easily offended by sexist humour, don't read this. ${ }^{* *}$ Disclaimer to the Disclaimer: I know not all lesbians are feminists and not all feminists are lesbians. But I stand by the boxer-briefs.

[The author goes on to describe his intent to create a "warning" list for a number of different kinds of women that male law students might interact with and a "how funny it'd be to fuck her" scale]

2. Girls you don't really know but is in law guy - sure you've creeped her in A2J big group, but what do you know about her. She could potentially ruin your law career, because her feminist man-hating vagina powers are unknown. She could also be a lesbian. I'd stick to casual flirting on Tuesday's.

Complexity-rating: $3 / 5$

... But How funny it'd be to fuck her: $2 / 5$ - two points cuz she could be freak

[After seven entries, this part of the blog ended with the following]

Stick to the guidelines boys and everything will be fine ... actually don't even bother - A Kill is A Kill - happy hunting!

\section{The Failure to Report Homophobic Graffiti in the Men's Washroom}

For at least a period of over one year (September 2006 to November 2007), male students at Windsor Law who used the washroom in the commons area witnessed homophobic graffiti including "SAMIR IS GAY"; "ARAB IS GAY" and "40s A FAG" etched into the stalls. ${ }^{82}$ Not a single student reported this homophobic and racist graffiti to the administration during this time. This incident is not in isolation. A number of students have reported incidents in which their colleagues openly expressed disgust at ho-

82 I am aware of the 06 date because a gay student confided in me that he saw the graffiti as one of his first experiences in law school. The graffiti was reported to the Administration in 2007 as one of a number of homophobic incidents at the law school. The stalls have now been painted. 
mosexuality. In November, 2007, the Dean and Associate Dean sent the following letter to all law students:

It has come to our attention that there have been a number of incidents during the Fall term which involved the use of abusive and hateful language which targeted our gay students in the Faculty of Law. Such behaviour is intolerable in any academic environment, and even more so in a Law School committed to Access to Justice and to the basic principles of equality. The Law School is committed to ensuring a safe and inclusive environment, and will not tolerate homophobic words and conduct. ${ }^{83}$

\section{Cyber-Bullying}

In July of 2008, someone claiming to be a prospective Windsor student posted a message on www.lawstudents. ca. He or she appeared concerned about a number of incidents that were taking place at the law school including "allegations of homophobia" and wanted to know more about the school's environment. In one of the responses, a Windsor law student named and attacked an openly gay first-year student:

... What you have here is someone who was in first year named [name deleted] that gets all hot and bothered about absolutely everything! Trust me, if you attend Windsor you will know who [name deleted] is within weeks! ... [H]e hit the roof over someone that used the word gay - yet another example of the gay community taking a word that they themselves changed the meaning of (i.e. gay used to mean happy) and is upset when anyone else tries to use it in their own way - as though one community can somehow "own" a word. It was blown out of proportion, there was absolutely, positive, no anti-gay intent behind it, which by definition would make it NOT a homophobic problem but rather just the wrong use of a word. ${ }^{84}$

\section{(c) Law Blog Entries}

One can also get a sense of the mind-set of many law students by examining some of the entries that have been posted on blogs like www.lawstudents.ca and www.lawbuzz.ca. Consider the following recent entry:

83 (27 November 2007). On file with the author.

84 Online: Law Students <http://www.lawstudents.ca/forums/viewtopic.php?t=15509\&sid=9c760 c19c1ffdfcca864fc3af8d89363> . 
"gay on Bay" [Law Buzz (16 July 2008)] $]^{85}$

This entry begins with someone asking "how gay friendly are toronto firms?" 86 Some of the responses include:

"I can't stand queens..."

"To all the people calling homosexuals and their deviant pastimes "gay", I implore you to use the correct terminology. There's nothing happy or cheery about sodomy between two guys. Be honest and call them homosexuals, don't fall victim to the propaganda machine." ${ }^{\prime 7}$

I recognize that there are limitations in using these blogs as an unprofessionalism yardstick. For example, it is possible that non-law students participate on these blogs. However, I suspect that this is a relatively infrequent occurrence and cannot explain topics where there are a significant number of participants.

\section{(d) Why Is This Occurring?}

Some of the incidents described above are expressions of hate, others likely the result of students struggling with having to confront issues of discrimination and difference in law school. There are other, more common and less offensive, incidents of unprofessional conduct that occur in law school every day. For example, there is much behaviour in law school that would be seen, by other students, as expressions of a sense of humour, however misguided rather than as discriminatory, demeaning, or uncivil. This is often not the product of hate or bias but rather immaturity. It is also the product of cultural incompetence and the failure of students to recognize the ways in which words and conduct perpetuate stereotyping and marginalization.

Other reasons for a professionalism crisis in law school include the absence of a professional culture and technology. A lack of professional culture includes students failing to appreciate their professional obligations, professors failing to teach legal ethics pervasively, the lack of meaningful mission statements and the failure of law professors, including sessional faculty, to sometimes serve as appropriate role models. Technology contributes to the problem because of its apparent anonymity and a 'write now, think later' mentality.

Finally, a core cause of unprofessionalism is the consumer culture that pervades law schools. It would seem that most students view themselves as students or consumers rather than as law students and as part of a community of professionals. Indeed, as one researcher found in his survey of law students in the United States “... at least a third or more --- took the position that, despite

85 Online: Law Buzz <http://www.lawbuzz.ca/index.php?showtopic=15545>.

86 It is unclear whether this was a legitimate search for information or an attempt to evoke homophobic responses.

87 For other offensive entries see "Pregnant in Law School" online: Law Buzz <http://www.lawbuzz. ca/index.php?showtopic=15415\&st=20>; "Law School and Girls", online: Law Buzz <http:// www.lawbuzz.ca/index.php?showtopic=6443\&st=0>; and, "Law School and Boys", online: Law Buzz <http://www.lawbuzz.ca/index.php?showtopic=15459\&hl=Law+School,and,Boys!>. 
being in a professional school, the concept of professionalism did not apply to them. Whatever professionalism might be... [it] would attach at graduation or after passing the bar examination. ... In the meantime, they considered themselves to be ... merely consumers of an educational product provided by the law school." ${ }^{8}$ A law school code of professional responsibility is one small step that can be taken, to ensure that students understand from day one, that they are an integral part of the profession and are obligated to act in a manner consistent with that role.

\section{CONCLUSION}

In his thoughtful article on the state of legal ethics in the Canadian academy, Adam Dodek observes that "[l] egal ethics has grown as an academic discipline in terms of both scholarship and course offerings... However, with these developments, we can also recognize that the ethical terrain yet to be explored is vast." ${ }^{\circ 9}$ One part of that unexplored terrain is the role and content of law school codes of conduct. This article has argued that all law students should be subject to a law school code of professional responsibility both to deter unprofessional conduct in law school but perhaps more importantly to prepare students for ethical practice by educating and inspiring them about the obligations owed by legal professionals.

How well will a law school code of conduct modelled on the rules governing lawyers fulfil these goals? ${ }^{90}$ This is the same question that so many ethics scholars have asked in relation to the Rules of Professional Conduct for lawyers. The general sentiment based on both experience and now some empirical research is that rules have little impact on ethical conduct either because lawyers ignore the rules; the rules are too general to address the myriad of ethical issues that arise on a dayto-day basis; or, because of the lack of vigorous and systemic enforcement. ${ }^{91}$

However, much of this discussion is less relevant in the law school context where the focus of a code should be on education and inspiration rather than regulation. Indeed, the central purpose of a law school code is to begin the professionalization of students. Moreover, even from a regulatory perspective, the range of activities that raise professionalism issues in law school are relatively small compared to actual practice and thus a code of conduct can be more com-

88 Timothy P. Terrell, "A Tour of the Whine Country: The Challenge of Extending the Tenets of Lawyer Professionalism to Law Professors and Law Students” (1994) 34 Washburn L.J. 1 at 19-20.

89 Dodek, supra note 2 at 48-49.

90 This question is explored in detail in Steven K. Bereson, "Education Law: What Should Law School Student Conduct Codes Do?” (2005) 38 Akron L. Rev. 803 at 825-834, 849-851.

91 See M.A. Wilkinson, C. Walker \& P. Mercer, "Testing Theory and Debunking Stereotypes: Lawyers' Views On the Practice of Law” (2005) 18 Can. J.L. \& Jur. 165; Julie Macfarlane, "Mediating Ethically: The Limits of Codes of Conduct and the Potential of a Reflective Practice Model" (2002) 40 Osgoode Hall L.J. 49; M.A. Wilkinson, C. Walker \& P. Mercer, "Do Codes of Ethics Actually Shape Legal Practice?" (2000) 45 McGill L.J. 645; Joan Brockman, "The Use of Self-Regulation to Curb Discrimination and Sexual Harassment in the Profession" (1997) 35 Osgoode Hall L.J. 209; and, Gavin MacKenzie, “The Valentine’s Card in the Operating Room: Codes of Ethics and the Failing Ideals of the Legal Profession” (1994-1995) 33 Alta. L. Rev. 859. 
prehensive than codes that govern the conduct of lawyers. I am optimistic that a law school code, properly drafted and accessible, can inspire and educate. My experience is that law students are highly motivated and anxious to learn about their professional responsibilities. A law school code provides students with a starting point and structure to engage in a dialogue about professionalism and a yardstick with which to measure their conduct. 